\title{
Rainfall and Temperature Variability Analysis of ZARS, Mandya in Karnataka, India
}

\author{
B.S. Sowmyalatha ${ }^{1 *}$, K.S. Shubhashree ${ }^{2}$ and V. Thimmegowda ${ }^{3}$ \\ ${ }^{1}$ Department of Agronomy, College of Agriculture, ZARS, V.C. Farm, Mandya-571 405, \\ University of Agricultural Sciences, Bengaluru, Karnataka, India \\ ${ }^{2}$ AICRP on Small Millets, ZARS, V.C. Farm, Mandya-571 405, University of Agricultural \\ Sciences, Bengaluru, Karnataka, India \\ ${ }^{3}$ ZARS, V.C. Farm, Mandya-571 405, University of Agricultural Sciences, Bengaluru, \\ Karnataka, India \\ *Corresponding author
}

\section{Keywords}

Rainfall,

Temperature,

Karnataka, Mandya,

Variability,

Monsoon, Season.

Article Info

Accepted:

04 April 2019

Available Online:

10 May 2019

\section{A B S T R A C T}

No doubt the climatic aberrations will severely set back agricultural development in most of the tropical countries particularly India, where an increasing share of the poorest and most vulnerable population resides. Zonal Agricultural Research Station is located at Mandya district of Karnataka lies under agro-climatic zone 6 (Southern dry zone) having longitude of $76^{\circ} 49.8^{\prime} \mathrm{E}$ and latitude of $12^{\circ} 34.3^{\prime} \mathrm{N}$ with 697 meters above mean sea level. Rainfall and temperature data of 28 years (1991-2018) obtained from Agromet observatory, Zonal Agricultural Research Station (ZARS), Mandya, University of Agricultural Sciences, Bengaluru was analysed for variability. The mean annual rainfall of the station is $735.9 \mathrm{~mm}$ distributes Pre-monsoon or summer (March-May) of $182.8 \mathrm{~mm}$, south-west monsoon (June-September)of $313.4 \mathrm{~mm}$, north-east monsoon (OctoberDecember) of $235.4 \mathrm{~mm}$ and winter season (January-March) of $4.2 \mathrm{~mm}$. The trend indicated that the maximum contribution was from south west monsoon $(42.59 \%)$ and lowest during winter $(0.57 \%)$ whereas September was the rainiest month $(130.66 \mathrm{~mm})$. The standard deviation (SD) was highest (123.4) with Co-efficient of variation (CV) of $39.40 \%$, which indicates high variability and dependability on rainfall from S-W monsoon. The mean monthly maximum temperature was $34.2^{\circ} \mathrm{C}$ and mean monthly minimum temperature was $14.4^{\circ} \mathrm{C}$. Mean annual maximum temperature was decreasing in a linear path contrastingly and mean minimum temperature was increasing linearly over the years. The annual rainfall variability indicates that 8 years received excess rainfall (21.6 to $57.5 \%)$, 12 years had normal rainfall (-4.0 to $10.4 \%), 2$ years with slight drought $(-19.1$ to $-19.2 \%)$ and 6 years of moderate drought $(-29.3$ to $-42.6 \%)$ were recorded. Overall analysis of rainfall and temperature shows variation in distribution and amount of rainfall received.

\section{Introduction}

Rainfall and temperature variability's are major factors influencing the agricultural productivity and sustainability in tropics Virmani (1994). Rainfall pattern and the quantity decide the cropping system in the rainfed agriculture. The annual and seasonal 
rainfall received and its variability directly influences the success or failure of crop through its favourable or adverse effect on crop growth and yield. Therefore, the study on variability of annual rainfall and temperature are essential in selection of suitable crops and to take up appropriate mitigating measures based on rainfall characteristics and temperature of a given location. Similar rainfall variability analysis was done by Mummigatti et al., (2013), Thimme Gowda et al., (2015) and Hanuman thappa et al., (2016). The monthly and seasonal pattern of rainfall and temperature may helpful in crop planning by identifying the period of drought, normal and excess rainfall (Ray et al., 1980). Such analysis is helpful in prediction of annual and seasonal rainfall probability for the next one or two years and in turn crop planning. Hence, a study was undertaken at Zonal Agricultural Research Station, Mandya district, Karnataka to understand the rainfall and temperature variability for better agricultural planning.

\section{Materials and Methods}

A study was taken on annual and seasonal rainfall and temperature variability analysis of Zonal Agricultural Research Station, which is located at Mandya district of Karnataka and lies under agro-climatic zone 6 (Southern dry zone) having longitude of $76^{\circ} 49.8^{\prime} \mathrm{E}$ and latitude of $12^{\circ} 34.3^{\prime} \mathrm{N}$ situated at 697 meters above mean sea level. Rainfall and temperature data of 28 years (1991-2018) was collected from Agromet observatory, Zonal Agricultural Research Station (ZARS), Mandya, University of Agricultural Sciences, Bengaluru. The rainfall and temperature data were collected on daily basis and analysed for standard deviation and Co-efficient of variance using statistical tools. Per cent deviation of rainfall from the normal were categorized using IMD classification viz., $\mathrm{E}=$ Excess RF (>19\%), N = Normal RF $( \pm 19 \%)$,
SLD $=$ Slight Drought $(>-19$ to $-25 \%), \mathrm{MD}=$ Moderate Drought ( -26 to $-49 \%) \mathrm{SD}=$ Severe Drought $(-50 \%$ \& above) (Anonymous, 2018).

\section{Results and Discussion}

Rainfall data for the period of 28 years from 1991 - 2018 was taken and mean was worked out to estimate the difference in rainfall pattern (Table 1). The rainfall data was then grouped to Southwest monsoon (Jun - Sep), Northeast monsoon (Oct - Dec), Winter (JanFeb) and Summer (March-May).

The mean annual rainfall of the station from the past 28 years was $735.9 \mathrm{~mm}$ distributed as $182.8 \mathrm{~mm}$ during pre-monsoon or summer season, $313.4 \mathrm{~mm}$ from South-West monsoon $235.4 \mathrm{~mm}$ from North-East monsoon and 4.2 $\mathrm{mm}$ during Winter season. The trend indicated that, maximum contribution of rainfall was from south west monsoon (42.59 $\%)$ and lowest during winter $(0.57 \%)$. High variability and dependability of rainfall from $\mathrm{S}-\mathrm{W}$ monsoon is indicated by highest standard deviation (SD) (123.4) with Coefficient of variation (CV) of $39.40 \%$ (Fig. $1)$.

\section{Annual drought analysis and rainfall variability on decadal basis of ZARS, Mandya}

The data on mean annual rainfall, coefficient of variation, standard deviation and its classification are given in Table 2 and 3. The annual rainfall variability during the last 28 years (1991 to 2018) indicates that 8 years received excess rainfall (21.6 to $57.5 \%), 12$ years with normal rainfall (-4.0 to $10.4 \%), 2$ years of slightly drought (-19.1 to $-19.2 \%)$ and 6 years moderate drought $(-29.3$ to -42.6 $\%)$ were recorded. However, the annual precipitation received in this region was normal (Table 2). 
Table.1 Seasonal rainfall pattern \& variability of ZARS, Mandya (1991-2018)

\begin{tabular}{|l|c|c|c|c|}
\hline Season & Avg. Rainfall & Per cent (\%) & SD & CV (\%) \\
\hline $\begin{array}{l}\text { South west Monsoon (June- } \\
\text { Sep) }\end{array}$ & 313.4 & 42.59 & 123.4 & 39.4 \\
\hline North east Monsoon (Oct- Dec) & 235.4 & 32.00 & 119.4 & 50.7 \\
\hline Winter (Jan-Feb) & 4.2 & 0.57 & 7.9 & 186.4 \\
\hline Summer (March- May) & 182.8 & 24.84 & 94.0 & 51.4 \\
\hline Annual (Total) & $\mathbf{7 3 5 . 9}$ & & $\mathbf{2 0 3 . 5}$ & $\mathbf{2 7 . 7}$ \\
\hline
\end{tabular}

SD -Standard Deviation CV-Co-efficient of variance

Table.2 Annual drought analysis of ZARS, Mandya (1991-2018)

\begin{tabular}{|c|c|c|c|c|}
\hline SI.No. & Year & $\begin{array}{l}\text { Average Rainfall } \\
\text { (mm) }\end{array}$ & $\begin{array}{c}\% \text { deviation from the } \\
\text { normal }\end{array}$ & Situation \\
\hline 1 & 1991 & 812.5 & 10.4 & $\mathrm{~N}$ \\
\hline 2 & 1992 & 425.8 & -42.1 & MD \\
\hline 3 & 1993 & 763.6 & 3.8 & $\mathrm{~N}$ \\
\hline 4 & 1994 & 520.0 & -29.3 & MD \\
\hline 5 & 1995 & 617.5 & -16.1 & $\mathrm{~N}$ \\
\hline 6 & 1996 & 1096.5 & 49.0 & $\mathrm{E}$ \\
\hline 7 & 1997 & 903.7 & 22.8 & E \\
\hline 8 & 1998 & 775.0 & 5.3 & $\mathrm{~N}$ \\
\hline 9 & 1999 & 935.2 & 27.1 & $\mathrm{E}$ \\
\hline 10 & 2000 & 1159.2 & 57.5 & E \\
\hline 11 & 2001 & 764.0 & 3.8 & $\mathrm{~N}$ \\
\hline 12 & 2002 & 436.9 & -40.6 & MD \\
\hline 13 & 2003 & 623.0 & -15.3 & $\mathrm{~N}$ \\
\hline 14 & 2004 & 956.7 & 30.0 & E \\
\hline 15 & 2005 & 1021.6 & 38.8 & E \\
\hline 16 & 2006 & 512.0 & -30.4 & MD \\
\hline 17 & 2007 & 630.4 & -14.3 & $\mathrm{~N}$ \\
\hline 18 & 2008 & 706.5 & -4.0 & $\mathrm{~N}$ \\
\hline 19 & 2009 & 779.7 & 6.0 & $\mathrm{~N}$ \\
\hline 20 & 2010 & 752.5 & 2.3 & $\mathrm{~N}$ \\
\hline 21 & 2011 & 791.0 & 7.5 & $\mathrm{~N}$ \\
\hline 22 & 2012 & 422.6 & -42.6 & MD \\
\hline 23 & 2013 & 595.6 & -19.1 & SLD \\
\hline 24 & 2014 & 951.1 & 29.3 & E \\
\hline 25 & 2015 & 594.7 & -19.2 & SLD \\
\hline 26 & 2016 & 485.6 & -34.0 & MD \\
\hline 27 & 2017 & 895.0 & 21.6 & E \\
\hline 28 & 2018 & 676.0 & -8.1 & $\mathrm{~N}$ \\
\hline
\end{tabular}

Mean $=735.9 \mathrm{~mm}$, IMD Classification: E= Excess RF $(>19 \%), \mathrm{N}=$ Normal RF $( \pm 19 \%), \mathrm{SLD}=$ Slight Drought $(>-$ 19 to $-25 \%), \mathrm{MD}=$ Moderate Drought $(-26$ to $-49 \%) \mathrm{SD}=$ Severe Drought (-50\% \& above)

Source: http://www.imdpune.gov.in 
Table.3 Annual Rainfall (mm) variability from 1991to 2018on decadal basis for ZARS, Mandya

\begin{tabular}{|c|c|c|c|}
\hline Decades & $\mathbf{1 9 9 1 - 2 0 0 0}$ & $\mathbf{2 0 0 0 - 2 0 1 0}$ & $\mathbf{2 0 1 0 - 2 0 1 8}$ \\
\hline Mean & 598.8 & 476.2 & 534.0 \\
\hline SD & 739.2 & 765.4 & 750.8 \\
\hline CV (\%) & 123.4 & 160.7 & 140.6 \\
\hline
\end{tabular}

SD -Standard Deviation CV-Co-efficient of variance

Table.4 Monthly rainfall variability of ZARS, Mandya

\begin{tabular}{|l|c|c|c|c|c|c|}
\hline \multicolumn{1}{|c|}{ Month } & Max. & Min. & Mean & SD & CV (\%) & $\begin{array}{c}\text { \% } \\
\text { contribution }\end{array}$ \\
\hline January & 15.6 & 0.00 & 1.60 & 4.11 & 257.35 & 0.22 \\
\hline February & 29.2 & 0.00 & 1.76 & 5.67 & 321.39 & 0.24 \\
\hline March & 172.0 & 0.00 & 15.25 & 34.97 & 229.28 & 2.11 \\
\hline April & 188.0 & 0.00 & 53.95 & 44.13 & 81.81 & 7.45 \\
\hline May & 304.0 & 0.00 & 109.90 & 81.19 & 73.88 & 15.17 \\
\hline June & 210.2 & 0.00 & 56.59 & 45.96 & 81.21 & 7.81 \\
\hline July & 120.8 & 1.20 & 48.39 & 32.27 & 66.68 & 6.68 \\
\hline August & 217.6 & 0.00 & 75.52 & 67.28 & 89.09 & 10.42 \\
\hline September & 363.5 & 30.40 & 130.66 & 79.95 & 61.19 & 18.04 \\
\hline October & 420.8 & 10.80 & 162.98 & 103.68 & 63.62 & 22.50 \\
\hline November & 256.8 & 0.00 & 55.23 & 56.93 & 103.10 & 7.62 \\
\hline December & 52.6 & 0.00 & 12.60 & 14.84 & 117.74 & 1.74 \\
\hline
\end{tabular}

Max- Maximum Min-Minimum SD -Standard Deviation CV-Co-efficient of variance

Table.5 Characteristics of monthly maximum temperature from 1991-2018 (28 years) at ZARS, Mandya

\begin{tabular}{|l|c|c|c|c|c|}
\hline Month & Max. & Min. & Mean & SD & CV (\%) \\
\hline January & 31.7 & 27.5 & 29.5 & 1.2 & 4.1 \\
\hline February & 38.0 & 29.0 & 31.7 & 1.8 & 5.7 \\
\hline March & 37.0 & 30.0 & 33.4 & 1.6 & 4.9 \\
\hline April & 37.0 & 31.5 & 34.2 & 1.4 & 4.2 \\
\hline May & 36.9 & 29.9 & 33.3 & 1.7 & 5.2 \\
\hline June & 32.7 & 28.3 & 30.7 & 1.2 & 3.9 \\
\hline July & 31.5 & 27.3 & 29.4 & 1.1 & 3.8 \\
\hline August & 38.0 & 27.1 & 29.7 & 2.1 & 6.9 \\
\hline September & 33.3 & 27.7 & 29.8 & 1.1 & 3.6 \\
\hline October & 34.5 & 26.7 & 29.8 & 1.6 & 5.3 \\
\hline November & 30.2 & 27.1 & 29.4 & 1.5 & 5.3 \\
\hline December & 29.0 & 26.8 & 28.7 & 1.5 & 5.3 \\
\hline
\end{tabular}

Max- Maximum Min-Minimum SD -Standard Deviation CV-Co-efficient of variance 
Table.6 Characteristics of monthly minimum temperature from 1991-2018 (28 years) at ZARS, Mandya

\begin{tabular}{|l|c|c|c|c|c|}
\hline Month & Max. & Min. & Mean & SD & CV (\%) \\
\hline January & 20.6 & 12.3 & 14.4 & 1.7 & 11.9 \\
\hline February & 21.1 & 11.0 & 15.9 & 1.9 & 11.7 \\
\hline March & 21.3 & 14.0 & 18.3 & 1.7 & 9.1 \\
\hline April & 29.9 & 16.4 & 21.0 & 2.2 & 10.6 \\
\hline May & 22.3 & 16.5 & 20.4 & 1.3 & 6.4 \\
\hline June & 22.8 & 17.3 & 20.1 & 1.1 & 5.3 \\
\hline July & 21.1 & 16.8 & 19.6 & 1.1 & 5.4 \\
\hline August & 21.1 & 15.8 & 19.6 & 1.1 & 5.6 \\
\hline September & 22.4 & 18.0 & 19.7 & 0.9 & 4.4 \\
\hline October & 21.2 & 17.3 & 19.4 & 0.9 & 4.6 \\
\hline November & 19.1 & 15.3 & 17.9 & 1.5 & 8.3 \\
\hline December & 16.7 & 12.2 & 15.7 & 2.1 & 13.6 \\
\hline
\end{tabular}

Max- Maximum Min-Minimum SD-Standard Deviation CV-Co-efficient of variance

Fig.1 Seasonwise rainfall (mm) over the period of 28 years (1991-2018)

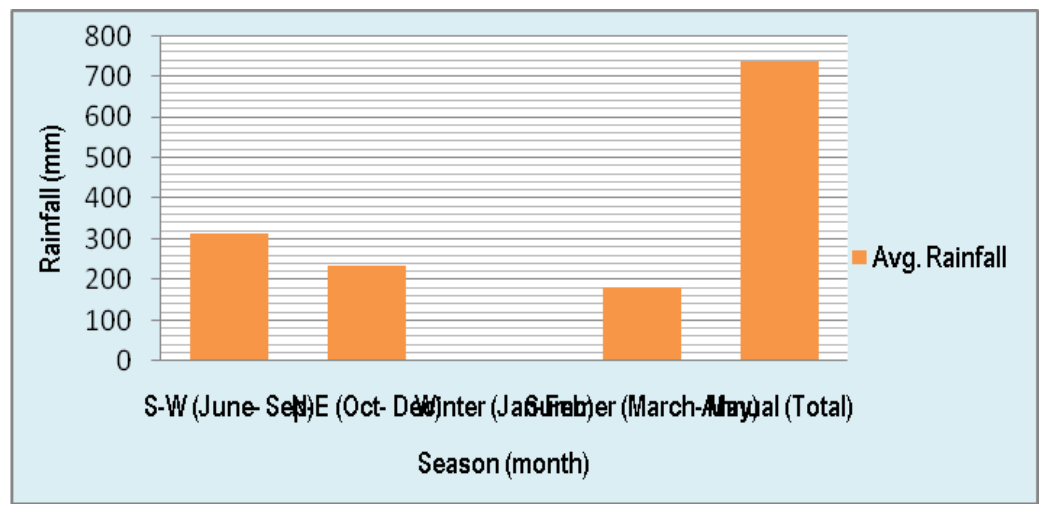

Fig.2 Rainfall trend at ZARS, Mandya (1991-2018)

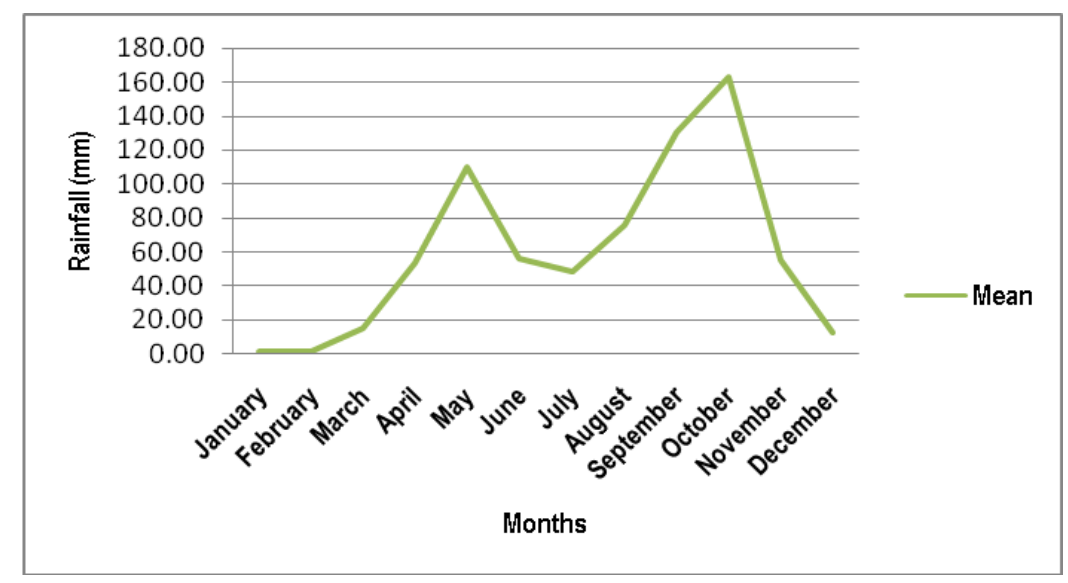


Fig.3 Characteristics of monthly maximum and minimum temperature of ZARS, Mandya

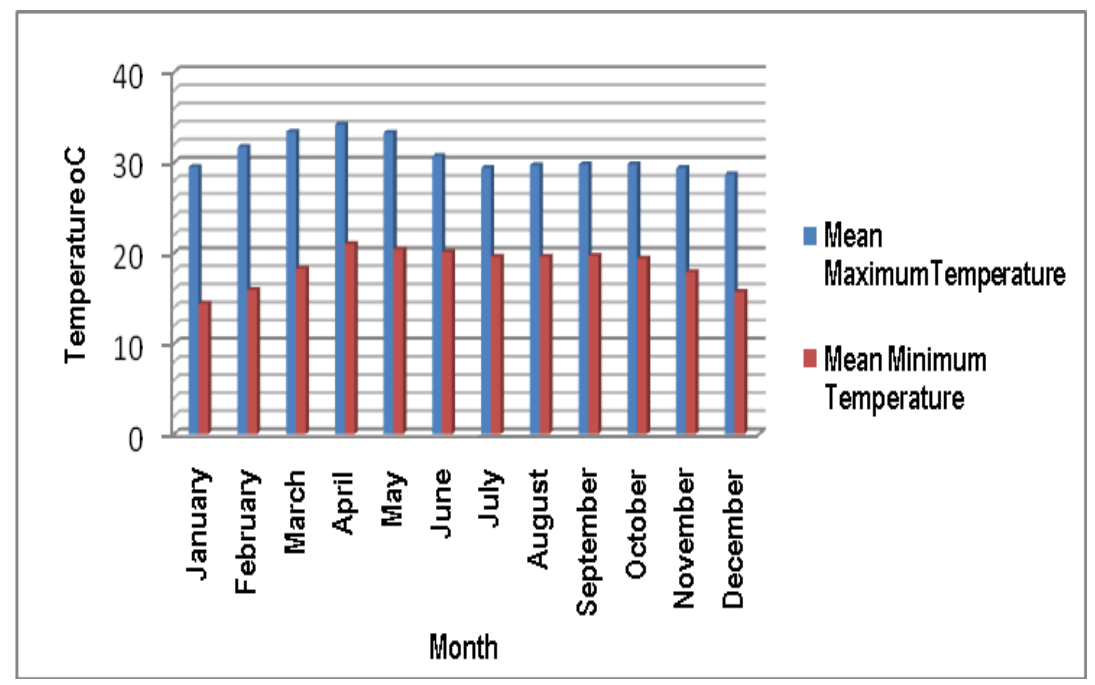

The decadal analysis (Table 3) indicated that over three decades, the average rainfall received was fluctuating and coefficient of variation was also varying. The highest average rainfall of $598.8 \mathrm{~mm}$ was received during 1991-2000 and lowest $476.2 \mathrm{~mm}$ during 2000-2010.

\section{Monthly rainfall variability}

The mean annual rainfall of ZARS was found to be $735.9 \mathrm{~mm}$ over the past twenty eight years. Mean monthly rainfall varied from 1.60 $\mathrm{mm}$ (lowest in January) to $162.98 \mathrm{~mm}$ (highest in October) (Table 4 and depicted in Fig. 2). The overall variability analysis of rainfall revealed that receipt of rainfall during the first three months (January to March) was less than $2.57 \%$. In the subsequent months April and May rainfall increased gradually to $22.62 \%$ whereas from June to October it reached maximum of $65.45 \%$. Similar results were observed from the findings of Tupe et al., 2010 and Singh et al., 2009.

\section{Monthly maximum temperature}

The overall variability of mean maximum temperature is presented in table 5 and depicted in Figure 3. The data on mean monthly maximum temperature over 28 years revealed that during summer season (March to May) maximum temperature ranged from 33.3 to $34.2{ }^{\circ} \mathrm{C}$, whereas in kharif season (June to September) it was 29.4 to $30.7^{\circ} \mathrm{C}$ and in Rabi season (October to February) it varied between 28.7 to $31.7^{\circ} \mathrm{C}$. Higher standard deviation and co-efficient of variation of 1.7 and 5.2 per cent was observed during the month of May in summer season, 2.1 and 6.9 per cent during August in Kharif and 1.8 and 5.7 per cent in winter (February), respectively.

\section{Monthly minimum temperature}

The mean minimum temperature variability is presented in table 6 and depicted in Figure 3. During summer season (March to May) mean monthly minimum temperature ranged from 18.3 to $21.0{ }^{\circ} \mathrm{C}$, whereas in kharif season (June to September) it was 19.6 to $20.1^{\circ} \mathrm{C}$ and in Rabi season (October to February) it varied between 14.4 to $19.4^{\circ} \mathrm{C}$. Higher standard deviation and co-efficient of variation of 2.2 and 10.6 per cent was observed during the month of April in summer season, 1.1 and 5.6 per cent during August in Kharif and 2.1 and 13.6 per cent in winter (December), respectively. 
In conclusion, the above study clearly indicates that significant variability in rainfall and temperature was noticed. The mean annual rainfall of $735.9 \mathrm{~mm}$ was received with maximum contribution from south west monsoon and lowest during winter. The highest standard deviation (SD) with lowest Co-efficient of variation (CV) indicates high variability and dependability on rainfall from $\mathrm{S}-\mathrm{W}$ monsoon. The annual rainfall variability during the last 28 years (1991 to 2018) indicates that 8 years received excess rainfall, 12 years with normal rainfall; 2 years of slightly drought and 6 years moderate drought were recorded. However, the annual precipitation receipt in this region was normal. Summer season recorded maximum temperature followed by Kharif and Rabi season.

\section{Acknowledgement}

Authors are thankful to ZARS, V.C. Farm, Mandya, University of Agricultural Sciences, Bengaluru, 560065, Karnataka, India.

\section{References}

Anonymous, 2018.http://www.imdpune.gov.in Hanumanthappa, M., Ranjith, T.H., Sridhara, S., Nagraj, R., Dhanjaya, B. and Sudhirkamath, K. V., 2016. Variability Analysis of Rainfall and Temperature on Growth and Yield of Different Kharif Crops at Udupi District of Karnataka. Advances in
Life Sciences. 5(21): 9655-9658.

Ray, C.R., Senapati, P.C., and Lal, R., 1980. Rainfall analysis for crop planning at Gopalpur, Orissa. Journal of Agriculture Enggneering. Pp. 384.

Singh, P.K., Lathore, L.S., Singh, K. K. and Baxla, A. K., 2009.Rainfall characteristics of North West alluvial plains of Bihar. Journal of Agrometerology.11(1): 37-41.

ThimmeGowda, P., Shruthi, G. K., Yogananda, S. B., 2015. Rainfall Trend Analysis of Mandya District in Karnataka. International Journal of Recent Research in Interdisciplinary Sciences (IJRRIS). 2(2): 16-20.

Tupe, A.R., Wanjari, S.S., and Bhale, V. M., 2010. Rainfall variability analysis for crop planning at Akola. In: Agro meteorological Services for farmers, ed. Vyas Pandey, Anand Agriculture University Anand. Pp. 46-50.

Mummigatti, U.V., Naveen, N.E. and Ninganur, B.T. 2013. Rainfall and rainy day trends at Dharwad, Karnataka. International Journal of Agricultural Sciences. 9(1): 237-241.

Virmani, S.M., 1994. Climate resource characterization in stressed tropical environment. Constraints and opportunities for sustainable agriculture. In: Stressed ecosystem and sustainable agriculture. Oxford and IBA publishing Co. (P) Ltd., New Delhi, India. pp. 149-160.

\section{How to cite this article:}

Sowmyalatha, B.S., K.S. Shubhashree and Thimmegowda, V. 2019. Rainfall and Temperature Variability Analysis of ZARS, Mandya in Karnataka. Int.J.Curr.Microbiol.App.Sci. 8(05): 4450. doi: https://doi.org/10.20546/ijcmas.2019.805.006 